\title{
EFFECTS OF A SCHOOL BASED INTERVENTION PROGRAM FOR ADOLESCENTS - WITH A SPECIAL FOCUS ON THE OVERWEIGHT/OBESE POPULATION
}

\author{
Michal Kudláček, Lisa James*
}

\author{
Faculty of Physical Culture, Palacký University, Olomouc, Czech Republic \\ * Faculty of Kinesiology and Rehabilitation Sciences, Catholic University of Leuven, Leuven, Belgium
}

Submitted in August, 2010

BACKGROUND: Obesity has become a pandemic, with more than a billion people affected worldwide. During the past two decades, the prevalence of obesity in children has risen greatly throughout the entire world. This is especially alarming in youth where the new prevalence is above predicted trends.

OBJECTIVE: This study was aimed at providing an intervention program for adolescents in the category of overweight/obese in accordance with physical activity (PA) guidelines. The total duration of the project was 8 weeks. The purpose of the study was to assess the effects of the intervention and promote lifelong participation in physical activities.

METHODS: The research sample was made up of high school students chosen in accordance with selected criteria of BMI between $25 \geq 35.5(\mathrm{n}=27)$. Data was collected from the participants through the use of questionnaires, internet, and pedometers, as well as objective measurements of height, fat and BMI using the Tanita Body Composition Analyzer.

RESULTS: Results showed that there was no reduction in BMI. There was also an increase in the amount of vigorous activity and number of steps throughout the intervention. According to Frömel and Bauman (2006), the logical significance of 240 MET minutes per week was seen in their study, whereas in our study we noticed a four times greater increase with 957 MET minutes per week, and logical significance in all types of PA.

CONCLUSIONS: In conclusion it was noted that increased activity reduces a sedentary lifestyle, while it improved social, mental and health status. In addition, our data indicate that sedentary behaviors are strongly related to overweight/obesity in adolescents. It also demonstrates that the type of model implemented with the intervention must reflect a holistic role and activities must critically reflect the interest and preferences of the participants, so that motivation to proceed is strong and conditions for adherence could be set up.

Keywords: Obesity, preference, interests, physical activity, physical education, lifestyle changes.

\section{INTRODUCTION}

Obesity is reaching epidemic proportions, afflicting a growing number of people in industrial and developing countries alike (Brown, 2000; Dehghan et al., 2005; Popkin \& Doak, 1999). The World Health Organization (WHO) projects that by 2015, approximately 2.3 billion adults will be overweight and more than 700 million will be obese (WHO, 2006). This is especially alarming in youths where the new prevalence is above predicted trends.

Tong and Fung (2003) quoting several authors, including Barlow and Dietz (1998); Must and Strauss (1999) suggested that the heightening of global concern with obesity can be attributed to the link between obesity and certain non communicable diseases and premature mortality. They suggested that the concern is heightened by research findings that indicate a positive relationship between obesity in childhood and overweight and obesity in adulthood.

Obesity in childhood causes a wide range of serious complications, and increases the risk of premature illnesses and death later in life, raising public health concerns. Results of research have provided new insights into the physiological basis of bodyweight regulation. However, treatment for childhood obesity remains largely ineffective.

The phenomenon is caused by perturbations of balance between food intake and energy expenditure, which is regulated by complex physiological systems requiring the integration of several peripherical signals and central coordination in the brain. A major contributing factor is physical inactivity which is closely related to bone health, cardiovascular disease risk, fitness and psychological factors. As obesity is the most common chronic disorder in industrialized societies, its impact on individual lives as well as on health economics has to be recognized more widely (Kiess, Reich, Meyer, Galler, Bennek, \& Kratzsch, 2001). This recognition of the problem has led to various research projects which have focused on prevention, environmental intervention, pediatric obesity treatment (clinical treatment), as well as nutritional and PA intervention. Crosnoe (2007) de- 
fines obesity as being the highest end of the body mass index (BMI), a ratio of height to weight.

Use of the BMI to assess overweight and obesity in children is more controversial. Since children are growing, there may be a looser link between adiposity or "true fatness" and the ratio of their weight to their height. PA is defined as any bodily movement produced by skeletal muscles that result in energy expenditure beyond resting expenditure (Sjöstrom et al., 2003; Thompson et al., 2003). Obesity is caused by an imbalance between energy input and energy expenditure. The relative contribution of PA, sedentary activity, and diet to the development of obesity in children is unclear, partly because these variables are difficult to measure and the balance of energy is complex. Other factors including genetic variation, epigenetic, intrauterine exposure, and assortative mating can also affect people's propensity to gain weight and may contribute in some populations to the epidemic (Kipping, Jago, \& Lawlor, 2008).

Skidmore and Yarnell (2004) are of the opinion that weight loss is more difficult to achieve and maintain in adulthood and that, therefore, prevention and treatment in childhood and adolescence is essential. Thus the use of PA or exercise therapies is more suitable for growing young obese subjects than for obese adult subjects due to pre-existing conditions brought on by obesity according to Parizkova, Chin, Chia, and Yang (2007).

Research carried out in a variety of disciplines such as pediatrics, nutrition and epidemiology have demonstrated that childhood obesity is not caused by one thing; rather, obesity results from the interplay of multiple factors. Such factors include environmental factors, lifestyle preferences, and cultural environment (Dehghan, Akhtar-Danesh, \& Merchant, 2005), cognitive and behavioral factors (Bascetta et al., 2006), sport preferences and interests (Kudláček, 2008). Gender has also been proven to affect obesity (Paulo, Cesar, \& Fernando, 2004). Warburton, Nicol, and Bredin (2006) say that routine PA has been shown to improve body composition, psychological and physiological factors. The benefits of PA are universal for all children, including those with chronic disease and disabilities (Huang, Sallis, \& Patrick, 2009). The purpose of the study was to assess the effects of the interventions and promote lifelong participation in physical activities.

\section{METHODS}

\section{Subjects and setting}

A total of three schools participated in the intervention program and baseline surveys (IPAQ, INDARES, and questionnaire).

Recruitment of participants was done via flyers sent to each of the participating schools after which a meet- ing was organized in order to present the program to prospective participants and teachers. Approximately 212 students signed up for the program, however, upon applying the selection criteria (BMI: $\geq 25$ to 35.5 ) twenty seven (27) participants (only girls) met the selection criteria. The average age of participants was 17.72 years ( \pm 2.29$)$, weight $78.43 \mathrm{~kg}( \pm 14.59)$, height $167.67 \mathrm{~cm}$ $( \pm 6.87)$.

Each participant was required to sign a consent form before commencing the intervention.

\section{Study design}

A non-randomized experiment style of comparative character was used as a study design. Data was collected from the test subjects through the use of questionnaires, internet, and a pedometer as well as measurements of height, fat and BMI from the Tanita Body Composition Analyzer.

The methodology subsequently focused on achieving the specific objectives identified in the research aims.

\section{OBJECTIVE 1}

To assess the effects of the intervention achieving sustained weight loss.

The International Physical Activity Questionnaires (IPAQ) was used to obtain comparable estimates of PA.

The long IPAQ was utilized at the start and end of the program. The long, self administered IPAQ covered five domains of PA: work related, transportation, housework/gardening, leisure time activity and sitting time. The questionnaire also included questions about time spent sitting as an indicator of sedentary behavior. In each of the four domains the number of days per week and time per day spent in both moderate and vigorous activity were recorded. At work, during transportation and in leisure time, walking time was also included. At the end of the program results from both were compared using the scoring protocol (available on http://www. ipaq.ki.se/).

The intervention program consisted in increasing the amount of physical activities undertaken by the target group in activities such as walking, cycling, strength exercises and others. Fitness tests designed specifically for the test subjects were used, since many common fitness tests had proven to be inadequate for testing obese youth. The running distances, times or weight used were decreased and equipment was modified as needed. Each component of fitness entailed two tests each with a grading system. The main categories of testing included:

- Strength: sit ups were done within a 30 second period. There were so called female pushups executed on the knees as well as "male" full length pushups. 
- Flexibility: the sit and reach test and shoulder flexibility test were used using a scale signifying that the fingers are more than 2 inches apart and overlapping.

- Power and speed: a distance of about 30-60 m apart is set and, upon receiving the signal, each participant must sprint as fast as possible to the end. Repeat twice and select the best time.

- Endurance - the Rockport walk: for this test you need a stopwatch and a 400 m track. Walk for 1 mile (1600 meters) as quickly as possible. As soon as you complete the distance, record your time and your heart rate.

- Endurance: knee bend-push up-knee bend-stand: the subject stands with legs together and hands along the body, bends both knees, then pushes-up, again bends their knees and then returns to the initial position. The number of complete cycles in 1 minute is counted.

The program was of eight weeks duration, wherein the subjects participated in these activities six days weekly for a period of approximately 40-60 minutes (including warm up and cool down periods). The program was analyzed to see whether it achieved its goal of reducing obesity, behavioral changes and promoting participation.

Two tools were used to evaluate the modification of body mass before and after the intervention. These instruments were the Tanita device (Body Composition Analyzer) type BC-418 MA and the Pedometer.

- The Tanita BC-418 MA Segmental Body Composition Analyzer is a single frequency BIA which is a simple, quick, and non-invasive means of measuring body composition, making it particularly useful for group screenings, a device that uses eight polar electrodes. This device uses a single point load cell weighing system in the scale platform, and it can provide separate body mass readings for different segments of the body such as right arm, left arm, trunk, right leg, and left leg.

- The Tanita BC-418 Body Composition Analyzer calculates "body fat ratio", "body fat mass", "fat free mass", "estimated muscle mass" and "Base Metabolic Rate" using data derived by the DXA method using BIA. An algorithm incorporating impedance, age, and height is used to estimate FM \%.

The procedure for using the equipment includes:

1. Calibrating the device.

2. Recording each subject's height, age and sex.

3. Each subject steps onto the weighing platform with bare feet so they touch the electrodes upon which their body weight and impedance measurements were taken and the overall body fat percentage was calculated.
- The Pedometer is a device that can record the amount of steps the participant has walked that day, and thus the kilometers or miles (distance $=$ number of steps $\times$ step length). The pedometer is useful in giving an indication of the level of PA of an individual.

Pedometers were all checked to ensure proper documentation before distribution. Participants were instructed to wear their pedometers on their belt or waistband in line with the knee. They were worn throughout the day. At the end of each day the number of steps and amount of energy in kilocalories expended were recorded in the pedometer record book.

Participants also recorded, in the pedometer record book, their physical inactivity throughout the day in terms of hours. Physical inactivity included time spent in television viewing, computer usage, at parks and restaurants, sports and cultural events, in public transport and others.

Power point presentations were also a part of the program and were sent on a weekly basis to the participants. Eight topics were selected such as an introduction, walking towards health, INDARES, stretching, fluid replacement, fitness and wellness, PA guidelines and nutrition.

\section{OBJECTIVE 2}

To measure the overall effectiveness of the program in:

a) sensitizing participants to the importance of physical activities;

b) to promote behavioral changes and sustained weight loss;

c) to promote lifelong participation in physical activities.

To measure the effectiveness of the program INDARES and a follow-up questionnaire were used. INDARES (International Database for Research and Educational Support), available on www.indares.com, is an online system where participants were registered. The system is focused on recording, analyzing and comparing of the data concerning the PA of its users (Křen, Chmelík, Frömel, Fical, \& Kudláček, 2008). INDARES system gives students an overview representation of their PA including immediate comparison of their results and compares those results with those of their classmates as well as helping them set up their own goals and check their fulfillment. It also serves as a complex overview representative of the groups to the teacher or administers and compares results of the different students in a class or group, eventually comparing the entire group by giving an overview of their sport preferences.

The sport activity preference survey was also used where each participant filled in his/her name, gender, 
weight, height, year of birth, institution (name and type of school) and grade. This standardized questionnaire is available on www.indares.com (Sigmund, Mitáš, Kudláček, \& Frömel, 2007). Participants were asked to note their type of sport activity and the number of hours a week. The type of sport activity was divided into winter and summer and in each area they selected their five favorite sport activities in which they would like to participate. This was indicated by using a cross next to their favorite activity under column 1 , the second choice under column 2 until the fifth column. If their most preferred activity was not on the list, they had to choose the most similar one (according to its content and concept). Upon completion of the questionnaire they were asked to think about their favorite sport activity and indicate it with a circle.

The follow up questionnaire was administered at the end of the program with the aim of getting feedback from the participants. This consisted of a total of 24 questions, 20 of which are based on options of 1 through 5 where 1 represented excellent and 5 poor and 4 open questions.

\section{Data analysis}

Basic descriptive statistics was used as a pre-test/ post-test design was implemented measuring each subject using measurements from the Tanita device and IPAQ questionnaire. Data was recorded and analyzed using the Statistica $8 \mathrm{CZ}$ program (StatsSoft.CR, 2008). For our statistical analysis we used basic statistics - descriptive statistics (means - M, standard - SD deviation, median - Mdn and interquartile range - IQR). The whole study has a descriptive character. For the evaluation of the level of significance we used logical significance based on the evidence provided by previous studies.

\section{RESULTS}

In TABLE 1 we observed an increase in the amount of PA in each variable. According to Frömel and Bauman (2006) a logical significance was seen of 240 MET minutes per week. We noticed a four time bigger increase with 957 MET minutes per week (compare to Frömel and Bauman), which stands for a logical significance in all areas. Referring to the IPAQ scoring manual we can also say that our results can be placed in the second category (moderate PA) which consists of a range between 600-3,000 MET minutes per week.

We also noticed a significant increase in the amount of vigorous activity of the participants by 30 minutes throughout the program showing a $69 \%$ increase as well as moderate activity with $6 \%$ and walking $4 \%$ increase (TABLE 2).

TABLE 3 shows a three times increase in the METminutes per week where job/school was concerned, the time spent during recreation activities also increased, but not so much in home and gardening.

\section{Assessing the effects of the intervention achieving sus- tained weight loss}

TABLE 4 reflects the mean and standard deviation scores of the Tanita measurements. It reflects that there was a slight decrease in BMI using the calculations for adults but there was no change in the calculations of the teen.

\section{TABLE 1}

Results of the IPAQ - physical activity in METs-min./week

\begin{tabular}{|l|c|c|c|c|}
\hline \multirow{2}{*}{ Type of activity } & \multicolumn{2}{|c|}{ Pre-test } & \multicolumn{2}{c|}{ Post-test } \\
\cline { 2 - 5 } & Mdn & IQR & 4,158 & 2,046 \\
\hline Walking & 3,201 & 1,815 & 4,515 & 4,551 \\
\hline Moderate PA & 3,505 & 4,113 & 3,240 & 5,220 \\
\hline Vigorous PA & 1,410 & 2,490 & 10,566 & 8,240 \\
\hline Total PA & 8,542 & 6,405 & & IQR \\
\hline
\end{tabular}

TABLE 2

Results of the IPAQ in min./week

\begin{tabular}{|l|c|c|c|c|}
\hline \multirow{2}{*}{ Type of activity } & \multicolumn{2}{|c|}{ Pre-test } & \multicolumn{2}{c|}{ Post-test } \\
\cline { 2 - 5 } & M & SD & 75.5 & SD \\
\hline Vigorous PA & 44 & 47.5 & 112 & 73 \\
\hline Moderate PA & 105.5 & 67 & 131.5 & 60 \\
\hline Walking & 126 & 55.5 & & \\
\hline
\end{tabular}


TABLE 3

Results of IPAQ in MET-minutes per week for PA in school, home and recreation

\begin{tabular}{|l|c|c|c|c|}
\hline \multirow{2}{*}{ Type of activity } & \multicolumn{2}{|c|}{ Pre-test } & \multicolumn{2}{c|}{ Post-test } \\
\cline { 2 - 5 } & Mdn & IQR & 1,200 & 1,680 \\
\hline Job/school & 400 & 1,111 & 1,330 & 2,460 \\
\hline Home \& gardening & 1,615 & 2,340 & 1,656 & 1,736 \\
\hline Recreation & 1,538 & 1,692 & IQR \\
\hline
\end{tabular}

TABLE 4

Results of Tanita measurements

\begin{tabular}{|l|c|c|c|c|}
\hline \multirow{2}{*}{ Variables } & \multicolumn{2}{|c|}{ Pre-test } & \multicolumn{2}{c|}{ Post-test } \\
\cline { 2 - 5 } & M & SD & 167.9 & 7.9 \\
\hline Height & 167.7 & 7.7 & 78.5 & 12.2 \\
\hline Weight & 79.2 & 12.6 & 27.8 & 3.2 \\
\hline BMITEEN & 28.0 & 3.4 & 28.2 & 3.2 \\
\hline Fat\% & 28.2 & 3.2 & 34.6 & 6.4 \\
\hline FATM & 34.8 & 6.7 & 27.2 & 6.6 \\
\hline FFM & 27.3 & 7.5 & 51.3 & 10.7 \\
\hline TBW & 51.5 & 10.3 & 37.6 & 7.8 \\
\hline BMR & 37.4 & 7.5 & 6,947 & 1,261 \\
\hline
\end{tabular}

Legend: BMI - Body Mass Index (adult), BMITEEN - Body Mass Index (teen), FATM - Fat Mass, FFM - Fat Free Mass, TBW - Total Body Water, BMR - Basic Metabolic Rate

\section{Measuring the overall effectiveness of the program}

A survey was administered at the end of the 8 weeks to evaluate the intervention program. Results showed that $48 \%$ of the participants were somewhat willing to participate in the intervention while another $33 \%$ were willing and $14.8 \%$ very willing $(4.2 \%$ were not willing to participate). $51.8 \%$ of the participants thought that the program was just "beneficial" to them while $41.1 \%$ thought it was very beneficial (Fig. 1).

When asked if they believed the program was a success, participants had varying views: $14 \%$ thought it was very successful, $48 \%$ believed it to be successful and $29.6 \%$ believed it was somewhat successful.

Nearly half the participants (48\%) reported that they felt supported by their peers throughout the program; in comparison $51.8 \%$ viewed family members as not being helpful. However, overall, a high percentage, $66 \%$, believed that the feedback from the community was positive. The majority of participants (66\%) believed that they were able to maintain a good attitude throughout the program. $74 \%$ pledged to continue exercising at least, on average, 2-3 days weekly.

An assessment of sedentary behavior before the intervention program showed that $18.5 \%$ spent more than 3 hours daily in sedentary activities, $66.6 \%$ spent 2-3 hours daily and $22.2 \%$ about an hour per day. In
Fig. 1

Benefits of the program - assessed by participants

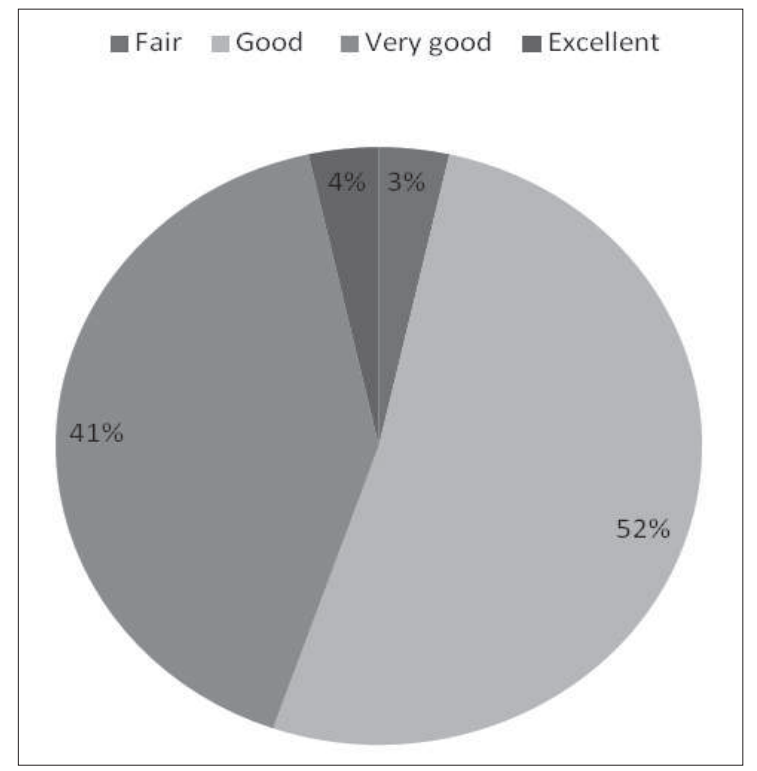

comparison, after the program there was a reduction in the number of participants who reported spending 2 or more hours being inactive (Fig. 2). 
Fig. 2

Sedentary behavior

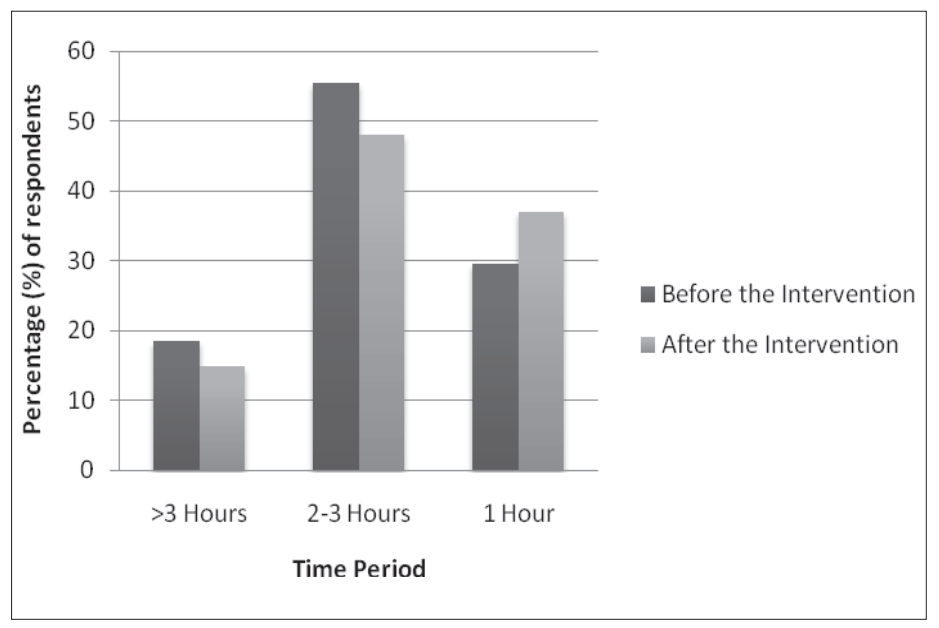

Based on the responses obtained, $51.8 \%$ of participants indicated that they had improved their knowledge in the areas of PA and healthy lifestyle, including $66.6 \%$ who thought their nutrition was enhanced.

The majority of subjects noted a positive mental change (70.3\% good, $22.2 \%$ very good and $3.7 \%$ excellent) and $100 \%$ confirmed there were good social changes during the intervention. Similarly $88.7 \%$ reported the physical change as good or very good.

Most participants agreed that they would partake in a similar program in the future since the majority believed that communication throughout the intervention was adequate. A majority count also showed that the use of the INDARES.COM project proved to be useful.

In general, participants believed that more control should have been exerted on the program and that com- munication could be improved. They believed that more regular meetings would have worked towards this end and would have provided them with additional guidance throughout the intervention. Similarly participants were of the opinion that the program could have been better if they were given a nutrition plan to follow. Others who showed interest in owning a pedometer believed that these could have been sold at a discounted rate to them as a reward for participating in the program. Of the participants, $70 \%$ were in total agreement to having a follow up within 6 months, $11 \%$ disagreed and 22\% were uncertain.

In terms of the number of steps taken on weekdays there was an increase of $27.7 \%$ and an $8 \%$ increase on weekends. This positive change was noticed from the commencement to the end of the program (Fig. 3).

Fig. 3

Number of steps taken - trend line (weekdays vs. weekends)

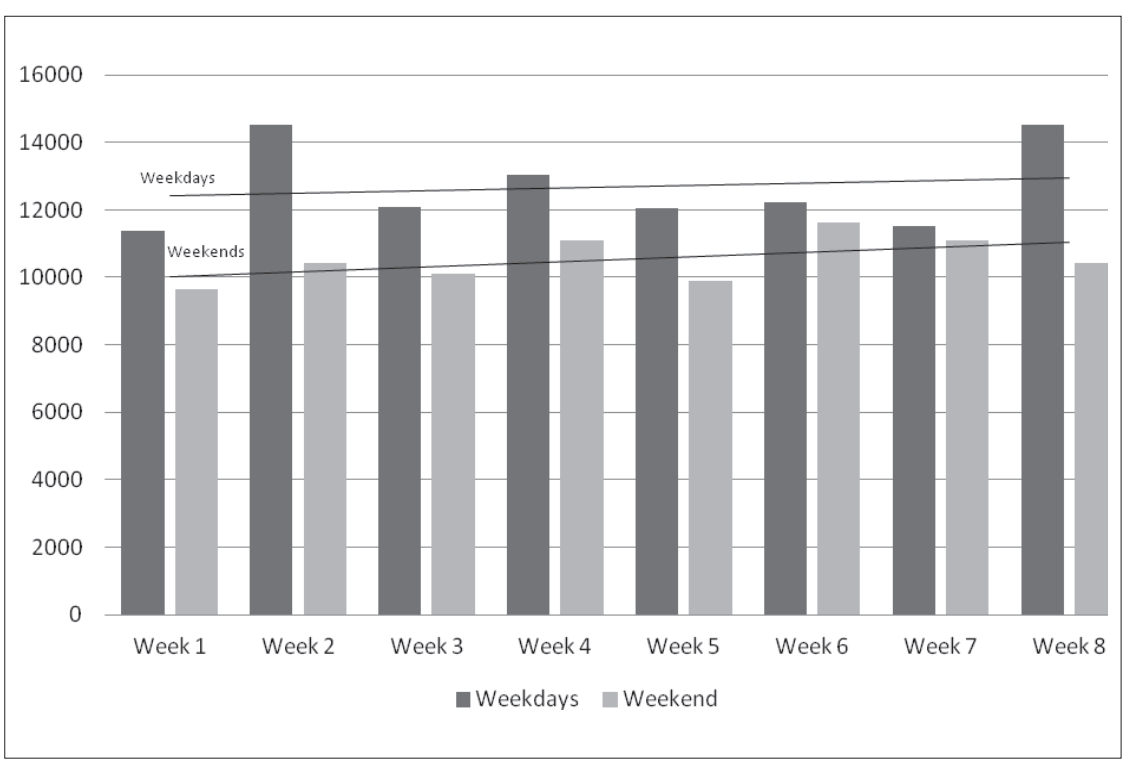


TABLE 5

Individual sport preferences

\begin{tabular}{|c|l|}
\hline $\mathbf{1 .}$ & Swimming \\
\hline $\mathbf{2 .}$ & Cycling (speed, outdoor, indoor) \\
\hline $\mathbf{3 .}$ & Skating (figure, speed) \\
\hline $\mathbf{4 .}$ & Downhill skiing (alpine, acrobatic, speed) \\
\hline $\mathbf{5 .}$ & Tennis (soft tennis) \\
\hline $\mathbf{6 .}$ & Snowboarding \\
\hline $\mathbf{7 .}$ & Badminton \\
\hline $\mathbf{8 .}$ & Bowling (skittles, pool, billiard, petanque) \\
\hline $\mathbf{9 .}$ & Table tennis \\
\hline $\mathbf{1 0 .}$ & Track and fields \\
\hline $\mathbf{1 1 .}$ & Shooting \\
\hline $\mathbf{1 2 .}$ & Canoeing, rowing \\
\hline $\mathbf{1 3 .}$ & Sport gymnastics \\
\hline $\mathbf{1 4 .}$ & Squash (ricochet, racquet ball) \\
\hline $\mathbf{1 5 .}$ & Golf (minigolf) \\
\hline $\mathbf{1 6 .}$ & Combined sports (triathlon, modern pentathlon) \\
\hline $\mathbf{1 7 .}$ & Cross-country skiing (biatlon, nordic combination) \\
\hline
\end{tabular}

Analyzing by the weeks it can be seen that participants were more active during weekdays than at weekends. Generally, throughout the 8 weeks there was an increase in the number of steps taken. In terms of steps taken during the weekdays the highest percentage jump (27.7\%) occurred between weeks 1 and 2 followed by the period between week 7 and 8 . The amount of steps reflected slight fluctuation from week 3 through 7 .

As it relates to the steps taken on weekends the biggest single increase occurred between weeks 5 and 6 ( $17 \%)$, followed by the period from week 3 to 4 (9\%). The amount of steps taken on weekends was more constant in comparison to those taken on weekdays.

Results from the INDARES survey permitted the identification of preferred activities.

The participants indicated that they preferred swimming as their top individual sport followed by cycling and skating (TABLE 5). Participants also indicated that volleyball was their top team sport followed by basketball, then baseball/softball, floorball and frisbee. Participants selected sports aerobics, power exercises and running (jogging) as their preferred activities for conditioning purposes. Among outdoor sport activities, the following activities were the most favored: swimming, bathing, water attractions, water jumping, in-line skating and bicycle touring.

\section{DISCUSSION}

The goal of the present research was to determine whether the intervention conducted among three sec- ondary schools could lead to a reduction in obesity levels, as well as produce positive behavioral changes in overweight or obese adolescents. However, the main behavioral change will be noticeable after a particular time period - at least 6 months after the program's completion - has passed. After this time, the positive influence on their adherence will be recognizable (Sallis et al., 1990). This aspect of the research was based on the ecological model as this proved to be the most fundamental to be applied to our study.

Based on the Applied Body Composition Assessment by Heyward and Wagner (2004) twenty four (24) of the participants fell into the category of overweight/ obese and 3 within the mid (optimal weight) category. While BMI is acceptable and practical in large trials it is not ideal as it does not distinguish between changes in muscle, bone and fat (Gorely, Nevill M., Morris, Stensel, \& Nevill A., 2009). Therefore the use of the Tanita Body Composition Analyzer provided some useful measurements such as fat percentage (\%).

The intervention yielded results despite the short term length of the program and the limited number of participants. The intervention was designed to promote a reduction in BMI levels through an increase in their level of PA, better nutrition, less sedentary time, among others. Despite the length of the study, results showed that there was a reduction in BMI levels after using the calculations for adults, but it remained the same after using the calculation for teens. In accordance with logical significance our results proved to be non-significant.

It is likely that longer term studies would be required to document more significant changes in BMI level. The results obtained were consistent with results obtained by Harris, Kuramoto, Schulzer, and Retallack (2009); whose meta-analysis indicated that school based PA intervention did not improve BMI. Therefore, such intervention is unlikely to have a significant effect on the increasing prevalence of childhood obesity.

It is possible that the level of PA prescribed in the intervention was insufficient to greatly improve BMI, either because of the quantity of PA in the intervention or the adherence of individual children to the intervention. It was also noticeable that participants were more active during weekdays than weekends. This could be due to school and other activities that they participated in on those days. Major increases in the number of steps taken were seen in the earlier and latter part of the program. A closer look at the results also reveal that between the third to seventh weeks there was not a significant increase in the level of PA, especially on weekends. This could be attributed to environmental factors such as rain that limited opportunities to participate in outdoor activities.

The intervention had an impact in improving each participant's knowledge of PA and a healthy lifestyle. Results showed that over $50 \%$ of the participants thought 
that the program was very useful in achieving this goal. The nutritional intake of these participating adolescents reflected positive improvements although a nutritional plan was not constructed for them. Instead of the nutritional plan a powerpoint presentation with specific topics regarding nutrition was used. Based on our findings, nutritional habits were probably positively influenced through the use of this powerpoint presentation.

The 8 week intervention program was useful in reducing the amount of time spent watching television, using the computer and playing video games. Jones, Hoelscher, Kelder, Hergenroeder, and Sharma (2006) obtained similar results. They concluded that the reduction in sedentary behavior observed in their study may have been due, in large part, to the provision of concrete suggestions, ideas and ways for students to keep active. Students were provided with tangible ideas and attractive alternatives to sedentary activity/TV watching (e.g. specific suggestions for being active in the evenings and on weekends; specific venues where they could enjoy PA, etc.). This no doubt contributed to the results obtained.

In terms of family involvement, based on the assessment carried out at the end of the program it was observed that $51.8 \%$ of the participants did not receive any encouragement from their home circle. There is strong evidence that such support systems increase time spent in and the frequency of PA, increasing physical fitness and aerobic capacity, and improving participants' confidence in their ability to exercise (Dowda, Dishman, Pfeiffer, \& Pate, 2007; Sallis, Hovell, \& Hofstetter, 1992; Sallis, Prochaska, \& Taylor, 2000). Although there were varying views from the participants about their evaluation of the program, only $7.4 \%$ thought it to be fair to poor while $92.6 \%$ considered it to be from good to very successful. Based on their views we can conclude that they did enjoy the program.

There were several strengths of our research such as the use of the pedometers which the participants were very enthusiastic about and the activities of the program as many in the final assessment mentioned.

Some interventions, such as SPARK (Sports, Play, and Active Recreation for Kids) and NAP SACC (Nutrition and Physical Activity Self Assessment for Child Care), individuals can acquire training in the program and use it in their own setting. Other programs might have certain elements, such as a curriculum, that program directors can obtain and use as part of a new intervention (Ward, Saunders, \& Pate, 2007).

\section{Limitations}

A few limitations presented themselves during our study and should be acknowledged.

- The number of participants is a problem for the enabling of the generalization of the results.

- A major limitation was that the results could not be used to assess the level of fitness of the participants.
- Direct contact with the participants was also limited; this was only done at the start and the end of the program. Since documentation depended entirely on the participant there was large room for error, and there were several cases of missing data.

- Due to unforeseen circumstances the duration of the program had to be reduced. There is little doubt that the length of the program influenced the results obtained.

\section{CONCLUSIONS}

In conclusion our data indicated that sedentary behavior is strongly related to overweight/obesity in adolescents. It also demonstrates that the type of model implemented with the intervention must reflect a holistic role and activities must critically reflect the interest of the participants, so that their motivation to proceed is strong.

It also identified that not only PA contributes to weight reduction in overweight/obese adolescents, but also nutrition and family support are critical. We observed that a significant increase in vigorous activity reflected a higher amount; therefore we concluded that participating in more vigorous activities will yield better results with this particular group.

We have also noticed that becoming more physically active does not only lead to weight reduction but also contributes towards positive changes in mental and social status which is beneficial for persons at that age group and will lead towards better health in the long term. The Sport Preferences Survey can serve as a tool for innovation in PA programs and can lead to the improvement of the participation/adherence of children and youth. Also developing standardized kinds of intervention that focus on family involvement using consistent dietary and exercise regimens, as well as behavioral changes, could be effective methods for weight loss.

\section{ACKNOWLEDGMENT}

The study has been supported by the research grant from the Ministry of Education, Youth and Sports of the Czech Republic (No. MSM 6198959221) "Physical Activity and Inactivity of the Inhabitants of the Czech Republic in the Context of Behavioral Changes”.

\section{REFERENCES}

Bascetta, C. A. (2006). Childhood obesity: Factors affecting physical activity [Research report No. GAO-07-260R]. Washington: United States Government Accountability Office. 
Brown, L. R. (2000). Obesity epidemic threatens health in exercise-deprived societies. Retrieved 16. 6. 2009 on: www.earth-policy.org/index.php?/plan b updates/2000/alert11

Crosnoe, R. (2007). Gender, obesity, and education. Sociology of Education, 80(3), 241-260.

Dehghan, M., Akhtar-Danesh, N., \& Merchant, A. T. (2005). Childhood obesity, prevalence and prevention. Nutrition Journal, 4, 24.

Dowda, M., Dishman, R. K., Pfeiffer, K. A., \& Pate, R. R. (2007). Family support for physical activity in girls from 8 th to 12 th grade in South Carolina. Preventive Medicine, 44(2), 153-159.

Ebbeling, C. B., Pawlack, D. B., \& Ludwig, D. S. (2002). Childhood obesity: Public health crisis, common sense cure. Lancet, 10(360), 473-82.

Frömel, K., Bauman, A., Bláha, L., Feltlová, D., Fojtík, I., Hájek, J., et al. (2006). The intensity and volume physical activity of the population aged 15-69 in the Czech Republic. Česká kinantropologie, 10(1), 13-27.

Gorely, T., Nevill, M. E., Morris, J. G., Stensel, D. J., \& Nevill, A. (2009). Effect of a school based intervention to promote healthy lifestyles in 7-11 year old children. International Journal of Behavioral, Nutrition and Physical Activity, 6(5), 1-12.

Harris, K., Kuramoto, L. K., Schulzer, M., \& Retallack, J. E. (2009). Effect of school based physical activity interventions on body mass index in children: A meta-analysis. Canadian Medical Association Journal, 180(7), 719-726.

Heyward, V. H., \& Wagner, D. R. (2004). Applied body composition assessment. Champaign, IL: Human Kinetics.

Huang, J. S., Sallis, J., \& Patrick, K. (2009). The role of primary care in promoting children's physical activity. British Journal of Sports Medicine, 43(1), 19-21.

Jones, D., Hoelscher, D. M., Kelder, S. H., Hergenroeder, A., \& Sharma, S. V. (2008). Increasing physical activity and decreasing sedentary activity in adolescent girls: The Incorporating More Physical Activity and Calcium in Teens (IMPACT) study. The International Journal of Behavioral Nutrition and Physical Activity, 5(42), 1-10.

Kiess, W., Reich, A., Müller, G., Meyer, K., Galler, A., Bennek, J., \& Kratzsch, J. (2001). Clinical aspects of obesity in childhood and adolescence - diagnosis, treatment and prevention. International Journal of Obesity, 25(1), 75-79.

Kipping, R. R., Jago, R., \& Lawlor, D. A. (2008). Clinical review obesity in children. Part 1: Epidemiology, measurement, risk factors, and screening. British Medical Journal, 337, 1824.

Křen, F., Chmelík, F., Frömel, K., Fical, P., \& Kudláček, M. (2008). Dotazníky PPA a IPAQ pro Indares.com [Computer software]. Olomouc: Centrum kinantropologického výzkumu, Univerzita Palackého.
Kudláček, M. (2008). Sport preferences survey - future of martial arts. Archives of Budo, 4, 101-105.

Must, A., \& Strauss, R. S. (1999). Risks and consequences of childhood and adolescent obesity. International Journal of Obesity, 23, 2-11.

Parizkova, J., Chin, M. K., Chia, M., \& Yang, J. (2007). An international perspective on obesity, health and physical activity: Current trends and challenges in China and Asia. Journal of Exercise Science and Fitness, 5(1), 7-23.

Paulo, M., Cesar, V., \& Fernando, B. (2004). Social, familial and behavioral risk factors for obesity in adolescents. Pan American Journal of Public Health, 16(4), 250-258.

Popkin, B. M., \& Doak, C. M. (1998). The obesity epidemic is a worldwide phenomenon. Nutrition Review, 56(4), 106-114.

Sallis, J. F., Howell, M. F., Hofstetter, C. R., Doder, J. P., Hackley, M., Caspersen, C. J., \& Powell, K. E. (1990). Distance between homes and exercise facilities related to frequency of exercise among San Diego residents. Public Health Reports, 105, 179-180.

Sallis, J. F., Hovell, M. F., \& Hofstetter, C. R. (1992). Predictors of adoption and maintenance of vigorous physical activity in men and women. Preventive Medicine, 21(2), 237-251.

Sallis, J. F., Prochaska, J. J., \& Taylor, W. C. (2000). A review of correlates of physical activity of children and adolescents. Medicine \& Science in Sports \& Exercise, 32(5), 963-975.

Sigmund, E., Mitáš, J., Kudláček, M., \& Frömel, K. (2007). Stability of physical activity preferences survey in physical education students aged 21-24. Acta Universitatis Palackianae Olomucensis. Gymnica, 37(2), 100-101.

Sjöström, M. et al. (2003). Making way for a healthier lifestyle in Europe: Monitoring public health nutrition in Europe. List of indicators. Summary report final version. European Commision.

Skidmore, P. M. L., \& Yarnell, J. W. G. (2004). The obesity epidemic: prospects for prevention. QJM: $A n$ International Journal of Medicine, 97(12), 817-825.

STATSOFT.CR. (2008). Statistica.Cz Verze 8.0 [Computer.Software]. Praha: StatSoft.

Thompson, P. D., Buchner, D., Pina, L. I., Balday, G. J., Williams, M. A., Marcus B. H., Berra, K., Blair, S. N., Costa, F., Franklin, B., Fletcher, G. F., Gordon, N. F., Pate, R. R., Rodriguez, B. L., Yancey, A. K., \& Wenger, N. K. (2003). Exercise and physical activity in the prevention and treatment of atherosclerotic cardiovascular disease. Circulation, 107, 3109-3116.

Tong, S., \& Fung, L. (2003). The congruence of two different height-weight ratios in estimating obesity prevalence: A study with Hong Kong children age 6 to 12. Journal of Exercise Science and Fitness, 1(2), $133-135$. 
Warburton, D. E. R., Nicol, C. W., \& Bredin, S. S. D. (2006). Health benefits of physical activity: The evidence. Canadian Medical Association Journal, 174(6), 801-809.

Ward, D. S., Saunders, R. P., \& Pate, R. R. (2007). Physical activity interventions in children and adolescents. Champaign, IL: Human Kinetics.

World Health Organization. (2006). Obesity and overweight. Factsheet no. 311.

\section{EFEKTY ŠKOLNÍHO INTERVENČNÍHO PROGRAMU PRO ADOLESCENTY - S DŮRAZEM NA JEDINCE S NADVÁHOU/OBEZITOU}

(Souhrn anglického textu)

VÝCHODISKA: $\mathrm{Z}$ obezity se stala pandemie, která celosvětově ovlivňuje přes miliardu lidí. Prevalence obezity za posledních dvacet let dramaticky stoupla, a to celosvětově. Tento fakt je obzvláště alarmující u mládeže, kde se statistiky prevalence dostávají nad predikované trendy.

CÍLE: Tato studie byla zaměřena na sestavení základního intervenčního programu pohybové aktivity (PA) pro adolescenty, spadající do kategorie nadváha/obezita. Celková délka programu byla 8 týdnů. Tvorba programu proběhla v souladu s oficiálními doporučeními pro pohybovou aktivitu. Účelem studie bylo ohodnocení efektivity intervence a podpora celoživotní účasti participantů na pohybové aktivitě.

METODIKA: Výzkumný soubor byl tvořen středoškolskými studenty. Kritériem pro výběr participantů byla BMI kategorizace $25 \geq 35$,5. Velikost výzkumného souboru byla 27 jedinců. Pro posouzení efektivity intervence bylo použito pre-test a post-test měření. Hlavními intervenčními nástroji byly dotazníky, internet (facebook), pedometry a přistroj Tanita, využívaný $\mathrm{k}$ měření tělesného složení.

VÝSLEDKY: Výsledky nepotvrdily snížení hodnot BMI. Dále jsme zaznamenali zvýšené množství intenzivní PA a počtu kroků v průběhu celého projektu. Věcná významnost rozdílu v úrovni PA byla ve studii Frömela a Baumana (2006) stanovena na úrovni 240 MET-minut/týden. V naší studii jsme zaznamenali nejnižší nárůst PA o > 957 MET-minut/týden u všech druhů PA.

ZÁVĚRY: Zvýšená pohybová aktivita redukuje sedavý životní styl, zlepšuje společenský, psychický a zdravotní status. Sedavý způsob života významně souvisí $\mathrm{s}$ nadváhou a obezitou u adolescentů. Způsob prezentace a zvolený intervenční model by měl splňovat prvky komplexnosti a kriticky reflektovat zájmy a preference participantů, a to především $\mathrm{z}$ důvodu zvýšené motivace a následně adherence.

Klícová slova: obezita, preference, zájmy, pohybová aktivita, tělesná výchova, změna životního stylu.

\section{Mgr. Michal Kudláček, Ph.D.}

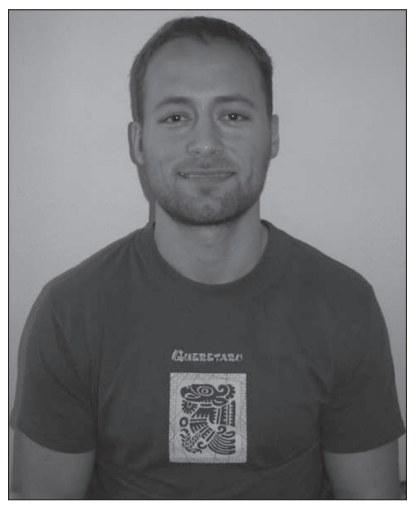

Palacký University

Faculty of Physical Culture

tř. Míru 115

77111 Olomouc

Czech Republic

Education and previous work experience

2005 - Palacký University, Faculty of Physical Culture Mgr. (equivalent MEd.) - physical education - biology. 2005 - teacher in high schools: Gymnázium Česká Třebová and Střední odborné učiliště Česká Třebová (vocational school).

2006 - teacher in Valdosta State University (1 semester). 2005-2008 - doctoral study program, Palacký University, Faculty of Physical Culture.

2010 - Palacký University, Faculty of Physical Culture Ph.D. - in kinanthropology.

Since 2008 - research assistant at Palacký University, Faculty of Physical Culture, Institute of Active Lifestyle, Olomouc, Czech Republic.

$\mathrm{He}$ is also working as a fitness coach in both commercial and professional areas.

\section{Scientific orientation}

The main area of interest is the environment of the adolescent population with special focus on sport preferences and physical activity of this particular group. He is also working on the INDARES.COM project.

\section{First-line publications}

Kudláček, M. (2008). Sport preferences survey - future of martial arts. Archives of Budo, 4, 101-105.

Kudláček, M., Frömel, K., Křen, F., \& Bebčáková, V. (2007). Struktura sportovních preferencí studentů středních škol. Tělesná Výchova \& Šport, 3-4, 10-13.

Kudláček, M., Frömel, K., \& Křen, F. (2007). Monitoring of structure of sport activity preferences in secondary school students [CD]. In B. Hodaň (Ed.), Movement \& Health. Olomouc: Univerzita Palackého.

Kudláček, Mi., Kudláček, Ma., Kudláček, V. Jr., \& Kudláček, V. (2010). Components/factors of the Czech version of the Physical Self Perception Profile (PSPP-CZ) among high school students. Acta Universitatis Palackianae Olomucensis. Gymnica, 40(4), 25-31. 